\title{
Sustainable functioning of the passenger transport logistics system
}

\author{
Liudmila Protasova, and Olga Zueva \\ Ural State University of Economics, 8 March Str., 63, 620014 Ekaterinburg, Russia
}

\begin{abstract}
The sustainable development of the transport logistics system (TLS) of passenger transportation in Russia is of great social importance for the mobility of the population. The purpose of the study is to check whether the course of the company JSC "FPC" for sustainable development, formulated in the strategy until 2030, is being implemented. The company has created a corporate quality system to improve the quality of services, ensure customer-oriented processes, and improve traffic safety. However, statistics show that the company's development is unstable, as the share of passenger traffic is small $-6,6 \%$ in 2012 and 5,5\% in 2019, and the volume decreased from 1421 to 1201 million people during this period. The majority of the population of the country chooses other modes of transport, because their need for mobility is not provided: the prices of railway tickets are high; also the travel time is significant, due to the low speeds of passenger trains. And the quality of the infrastructure (the state of the railway track and tracks) currently does not allow organizing highspeed movement of modern transport on the territory of the country; serious investments are needed to solve this problem.
\end{abstract}

\section{Introduction}

Sustainable development is development in which the needs of present generations are met without compromising the future generations to meet their own needs. This formulation first appeared in 1987 in the report "Our Common Future" [1]. A sustainable economy is an important element of sustainable development. The sustainable economy thrives on income from the rational use of natural, material, and human resources [2].

The modern concept of sustainable development includes three elements: social, economic and environmental. The sustainable development of the transport logistics system (TLS) of passenger transportation in Russia is of great social importance, primarily for the mobility of the population. Since the area of the country's territory is significant, the population is uneven, and the distances between the subjects are large.

A sustainable transport and logistics system for passenger transportation should be costeffective, so it is necessary to minimize logistics costs. In [3], the authors propose an economic and mathematical model for reducing logistics costs in the framework of a clientoriented approach to investment planning.

Sustainability is stability: the ability of the transport and logistics system to maintain a stable level of service quality over a long period of time. Sustainability is also important in management. Only a stable system, including transport and logistics, is manageable [4]. In 
[5], we summarized the problems that do not contribute to the sustainable development of the TLS of railway freight transport and we also proposed a process approach for effective management of Russian Railways processes based on GOSTR ISO 9000 series standards, which will ensure the achievement of the company's stated goal of reducing unproductive costs.

Since the sustainable development of the transport and logistics system of passenger transportation also contributes to the sustainable development of the country's economy, the topic of the study is relevant.

The object of the study is the TLS of the federal passenger company JSC "FPC", which provides long-distance passenger transportation services. The purpose of the study is to check whether the company is implementing the course for sustainable functioning, formulated in the development strategy until 2030.

Quality management technologies contribute to sustainable development, so the company's management is developing a Corporate quality Management System based on international standards ISO 9000 series. In accordance with the principle of customer orientation, the mission of JSC "FPC" is defined»: "WE improve the quality of life by making your trip as safe, affordable, and comfortable as possible." The quality policy and objectives have been approved, in particular, such as reducing the number of train delays; reducing the number of complaints about passenger service; achievement of the level of customer focus $>95 \%$; implementation of the staff development plan; obtaining the ISO 9001 certificate of compliance for all types of activities of JSC " FPC " [6].

Indeed, the quality system allows us to ensure customer-oriented processes, increase the efficiency, reliability and safety of traffic on the basis of quality control of technological and business processes. A process approach is being implemented in managing the quality of FPC's business processes: passenger transportation, ticket sales, passenger service, baggage and cargo baggage transportation, repair and maintenance of rolling stock. The requirements for the quality of services are defined in the relevant regulatory documents and standards of the organization, some of them are shown in table 1.

Table 1. Quality regulatory documents and organization standards [7]

\begin{tabular}{|c|c|c|}
\hline Regulatory documents & Internal standards & Internal documents \\
\hline $\begin{array}{l}\text { Order of the Ministry of } \\
\text { Transport of the Russian } \\
\text { Federation No. } 473 \text { of } \\
19.12 .2013 \text { " On Approval of } \\
\text { the Rules for the Carriage of } \\
\text { Passengers, Baggage, and } \\
\text { Cargo by Rail» }\end{array}$ & $\begin{array}{l}\text { Service standard STO FPC } \\
1.05 .006 .2015 \text { "Passenger } \\
\text { service in trains of the } \\
\text { formation of JSC" FPC» }\end{array}$ & $\begin{array}{l}\text { Code of Business Ethics of } \\
\text { JSC "FPC" approved by the } \\
\text { Board of Directors of JSC } \\
\text { "FPC" in Minutes No. } 8 \text { of } \\
14.12 .2015 \text {. }\end{array}$ \\
\hline $\begin{array}{l}\text { Federal Law No. 16-FZ of } \\
\text { February 9, 2007 " On } \\
\text { Transport Security» }\end{array}$ & $\begin{array}{l}\text { Service standard STO FPC } \\
1.21 .002-.2013 \\
\text { "Requirements for the } \\
\text { equipment of passenger cars } \\
\text { with removable textile } \\
\text { equipment» }\end{array}$ & $\begin{array}{l}\text { "Rules on the ethics of social } \\
\text { communication in the service } \\
\text { of passengers with limited } \\
\text { mobility on railway } \\
\text { transport" (ORDER of JSC } \\
\text { "Russian Railways" of } \\
\text { August 27, 2013 N 1835r). }\end{array}$ \\
\hline
\end{tabular}

The Internal Control and Audit Center of JSC "FPC" controls the quality of services in trains and ticket sales points by conducting audits and developing corrective actions. 


\section{Methods}

Theoretical research methods are based on a set of scientific ideas about sustainable development, logistics transport systems, and quality management. The methods of analyzing statistical data on passenger transportation, passenger traffic, and quality management approaches were used to identify problems in the logistics system of passenger transportation by rail in Russia.

\section{Analysis of the logistics system of passenger transportation by rail}

It should be noted that the implementation of the Corporate Quality Management System in JSC "FPC" has yielded positive results in the field of safety of railway passenger transportation services, so the number of accidents in the average of 8 years was 12,75 (Table 2). The causes of accidents in most cases on the railway are unsatisfactory technical conditions of the tracks.

Table 2. Passenger transportation and passenger traffic by rail in Russia $[8,9]$

\begin{tabular}{|l|c|c|c|c|c|c|c|c|}
\hline Year & 2012 & 2013 & 2014 & 2015 & 2016 & 2017 & 2018 & 2019 \\
\hline $\begin{array}{l}\text { Passen } \\
\text { ger } \\
\text { transpo } \\
\text { rtation, } \\
\text { total } \\
\text { million } \\
\text { people }\end{array}$ & 21370 & 19652 & 19558 & 19095 & 18645 & 18439 & 18113 & 17823 \\
\hline $\begin{array}{l}\text { By } \\
\text { railway }\end{array}$ & 1421 & 1080 & 1076 & 1025 & 1040 & 1121 & 1160 & 1201 \\
\hline $\begin{array}{l}\text { Relativ } \\
\text { e } \\
\text { share, } \\
\%\end{array}$ & 6,6 & 5,5 & 5,5 & 5,3 & 5,5 & 6,0 & 6,4 & 6,7 \\
\hline $\begin{array}{l}\text { Total } \\
\text { passeng } \\
\text { er } \\
\text { traffic, } \\
\text { billion } \\
\text { passeng } \\
\text { er-km }\end{array}$ & 532,6 & 547,2 & 556,2 & 529,7 & 519,4 & 560,2 & 593,6 & 635,2 \\
\hline $\begin{array}{l}\text { By } \\
\text { railway }\end{array}$ & 144,6 & 138,5 & 130,0 & 120,6 & 125,6 & 123,1 & 129,5 & 133,6 \\
\hline $\begin{array}{l}\text { Relativ } \\
\text { e } \\
\text { share, } \\
\%\end{array}$ & 27,6 & 25,3 & 23,4 & 22,7 & 24,2 & 21,9 & 21,8 & 21,0 \\
\hline $\begin{array}{l}\text { Accide } \\
\text { nt rate, } \\
\text { number } \\
\text { of } \\
\text { acciden } \\
\text { ts }\end{array}$ & 1 & 17 & 15 & 15 & 12 & 14 & 10 & 18 \\
\hline
\end{tabular}

Indicators of the functioning of the TLS are the volume of passenger traffic and passenger traffic, statistics from 2012 to 2019 according to Rosstat are shown in table 2 . 
As can be seen from Table 2, the volume of passenger traffic from 2012 to 2019 was constantly decreasing, from 21370 to 17823 million people, 1421 and 1201 million people were transported by rail, which accounted for $6 / 6 \%$ and $5,5 \%$, respectively, of the total number of passenger traffic.

The dependence of passenger traffic is non-linear, the minimum value was in 2016 519,4 billion passenger-km, the maximum in $2019-635,2$ billion passenger-km The share of passenger traffic by rail was 27,6 and $21 \%$ of the total turnover.

These data do not indicate the stable functioning of the FPC TLS. It remains to be seen what the root of the problem is.

Let us compare prices for May holidays from Yekaterinburg to Moscow, St. Petersburg, Sochi, Kazan and Kaliningrad round-trip (Table 3).

Table 3. Ticket prices for the May holidays of 2021 [10]

\begin{tabular}{|l|l|l|l|l|l|l|l|}
\hline round trip & $\begin{array}{l}\text { Dista } \\
\text { nce } \\
\text { by } \\
\text { railw } \\
\text { ay, } \\
\text { km }\end{array}$ & $\begin{array}{l}\text { Avera } \\
\text { ge } \\
\text { speed } \\
\text { km-h }\end{array}$ & Trip time & $\begin{array}{l}\text { Rese } \\
\text { rved } \\
\text { seat, } \\
\text { ruble } \\
\text { s }\end{array}$ & $\begin{array}{l}\text { Compa } \\
\text { rtment, } \\
\text { rubles }\end{array}$ & $\begin{array}{l}\text { First } \\
\text { class, } \\
\text { rubles }\end{array}$ & $\begin{array}{l}\text { VIP, } \\
\text { rubles }\end{array}$ \\
\hline $\begin{array}{l}\text { Yekaterinburg- } \\
\text { Moscow }\end{array}$ & 1417 & 47 & $\begin{array}{l}27 \mathrm{~h} .26 \mathrm{~min} .- \\
32 \mathrm{~h} .53 \mathrm{~min}\end{array}$ & 5886 & 10670 & 17776 & 24149 \\
\hline $\begin{array}{l}\text { Yekaterinburg- } \\
\text { Saint } \\
\text { Petersburg }\end{array}$ & 1782 & 49,5 & $\begin{array}{l}35 \mathrm{~h} .10 \mathrm{~min} .- \\
36 \mathrm{~h} .40 \mathrm{~min}\end{array}$ & - & 3900 & 5976 & - \\
\hline $\begin{array}{l}\text { Yekaterinburg- } \\
\text { Sochi }\end{array}$ & 2077 & 31 & $\begin{array}{l}58 \mathrm{~h} .27 \mathrm{~min} .- \\
75 \mathrm{~h} .36 \mathrm{~min} .\end{array}$ & 5851 & 10445 & 21633 & - \\
\hline $\begin{array}{l}\text { Yekaterinburg- } \\
\text { Kazan }\end{array}$ & 718 & 51,3 & $\begin{array}{l}12 \mathrm{~h} .52 \mathrm{~min} .- \\
15 \mathrm{~h} .6 \mathrm{~min} .\end{array}$ & 1982 & 4544 & 8935 & 14927 \\
\hline
\end{tabular}

It becomes clear, from the data in table 3, why the share of passenger traffic is small, and the volume of passenger traffic is decreasing annually (see table 2). The majority of the country's population does not choose rail transport, as ticket prices are high - at the level of air tickets for the low coaster "Pobeda flights", the long travel time is due to the very low average speeds of passenger trains from $31 \mathrm{~km} / \mathrm{h}$ to $51,3 \mathrm{~km} / \mathrm{h}$. For comparison, the train "Lastochka" overcomes the distance from Moscow to St. Petersburg at the average speed of $92 \mathrm{~km} / \mathrm{h}$, and the average speed of the high-speed "Sapsan" is about $172 \mathrm{~km} / \mathrm{h}$.

\section{Conclusions}

Thus, despite the increase in the quality of services provided on long-distance trains, JSC "FPC" cannot fully meet the needs of passengers in the quality of services, since the population's need for mobility is not met. The problem lies in the low quality of the infrastructure: the unsatisfactory technical condition of the railway tracks, which does not allow organizing high-speed movement of modern transport on the territory of the country. Therefore, serious investments in infrastructure are needed, as the lack of modern railway lines hinders the sustainable development of the TLS.

\section{References}

1. WCED Report, Oxford University Press, 2 (1987)

2. Sustainable economy, 3 (2018), https://answr.pro/

3. Liu Dan, Audit and Financial Analysis, 1, p. 263, (2018) 
4. D.D. Boursens, D.D. Clos, Logistics: an integrated supply chain, 635 (2017)

5. L.G. Protasova, 2nd International Scientific and Practical Conference "Modern Management Trends and the Digital Economy: from Regional Development to Global Economic Growth" (MTDE 2020), p. 1083 (2020), https://www.atlantis-press.com/

6. Official site of JSC "FPK", fpc.ru

7. The annual report of JSC FPC was approved by the decision of the Board of Directors of JSC FPC dated May 24, 2019 (Minutes No. 22 dated May 27, 2019)

8. Russia in numbers (2020), https://www.gks.ru/

9. Russia in numbers (2019), https://www.gks.ru/

10. RZD, https://ticket.rzd.ru/ 